\title{
Analysis of Childhood Physical Violence Cases Presented to the Emergency Department
}

\author{
(1) Güleser Akpınar
}

Clinic of Emergency Medicine, Düzce University Facuty of Medicine, Düzce, Turkey

\begin{abstract}
Aim: To examine the demographic and epidemiological characteristics of children who were exposed to physical violence.

Materials and Methods: Data of patients younger than 18 years admitted due to physical violence exposure to the Emergency Medicine Clinic in a tertiary university hospital were retrospectively reviewed.

Results: A total of 120 cases met the study criteria. The median age of patients was 15 (4-18) years and $70.8 \%$ of them were male. The female/ male (F/M) ratio was 35/85. Emergency admissions due to physical exposure were made most frequently in July $(n=16,13.3 \%)$, where in $57.5 \%$ were made between 16:00 and 23:59. The most common injury site was the head ( $n=39,32.5 \%)$ followed by the extremities $(n=21,17.5 \%)$. Moreover, $87.5 \%$ of patients had minor injuries according to Injury Severity Score levels.

Conclusion: Most of pediatric forensic cases were male adolescents. Education about a safe environment should be provided by taking protective measures to reduce the incidence of these cases. In addition, awareness activities in which parents and children can participate effectively should be supported and expanded by social institutions.
\end{abstract}

Keywords: Emergency service, physical violence, pediatric patient

\section{Introduction}

Exposure to physical violence and assault are significant public health problems. In the last decade, there has been an increase in the visits to the emergency service associated with such childhood injuries and pediatric abuse cases worldwide $(1,2)$. In 2017, the World Health Organization estimated that around one billion minors aged between 2 and 17 were exposed to physical, emotional, or sexual abuse. Childhood injury is among the leading causes of death worldwide, constituting approximately $40 \%$ of all childhood deaths (3).

Various studies conducted in Turkey have reported prevalence rates of pediatric forensic assault cases varying between $6.1 \%$ and $19 \%(4)$.
Pediatric forensic cases constitute a particular group in terms of management and processes due to the differences in children's anatomical, physiological, and psychological profiles. It is essential to characterize the types of pediatric forensic cases presenting to the emergency service concerning sex, age, and diagnosis $(5,6)$. Most studies performed on children and adolescents focus on only specific anatomical areas, a single injury mechanism (gunshot injuries, sexual assault, non-accidental trauma), or all pediatric forensic cases collectively $(7,8)$.

Childhood exposure to physical violence has further importance in pediatric cases where a good case history cannot be taken (9). The Glasgow Coma Scale (GCS) and Injury Severity Score (ISS) can evaluate trauma in children. GCS is also used for pre-verbal children. ISS is an anatomical score and is appropriate for patients with multiple injuries (10). 
Very few articles have been published on the types of pediatric forensic cases or these patients' characteristics in Turkey. To develop protocols, standards, and education programs regarding the approaches and precautions concerned with forensic cases in Turkey, the types of pediatric forensic cases, and the contributing factors need to be defined. Moreover, being informed about the pediatric forensic cases frequently encountered in emergency services and the demographic characteristics of these children would also increase the awareness of health officers employed in emergency services (4). To contribute to the literature, we aimed to determine the demographic and epidemiological characteristics of the cases presenting to our emergency service due to child exposure to physical violence and compare these with the literature data.

\section{Materials and Methods}

\section{Design and Setting}

Study data were obtained by retrospectively reviewing the data of patients younger than 18 years who presented to the emergency medical clinic with the complaint of exposure to physical violence between 01/01/2015-31/12/2019, accessed via the hospital information processing system and archived records. An ethics approval was obtained from Düzce University Ethics Committee (approval number: 2020/223, date: 19/10/2020).

\section{Study Population}

The patients' age, sex, GCS, ISS, presentation time, cause of the incident, and site of injury data were evaluated. Statistical correlations between these parameters and mortality were determined.

Patients who presented to the Emergency Medicine Department outside the study period (01/01/2015-31/01/2019) or had insufficient data were excluded from the study.

\section{Statistical Data Analysis}

The normality condition was tested using the Shapiro-Wilk test for continuous variables. Differences between two groups were analyzed using the Mann-Whitney $\mathrm{U}$ test, differences between three or more groups were analyzed using the Kruskal-Wallis test. Correlations between two categorical variables were investigated using the Pearson chi-square and Fisher's Exact tests. Continuous variables were reported as median (Interquartile range) and minimum (min)-maximum (max) values. Categorical variables were presented as percentages. IBM SPSS Statistics for Windows, Version 23 (Armonk, NY: IBM Corp) was used for all statistical analyses. The level of significance was defined as $p<0.05$.

\section{Results}

Between 2015 and 2019, 120 children presented to the emergency service due to exposure to physical violence. The patients' median age was 15 (4-18) years, and $70.8 \%$ were male. The female/male $(\mathrm{F} / \mathrm{M})$ ratio was $35 / 85$. Of the presentations, $57.5 \%$ were made between the hours 4:00 p.m-11:59 p.m. (Table 1).

The number of cases, which varied between one and three between 2011 and 2015, rose to 25-27 between 2015 and 2018. However, it declined to five in 2019. Cases were encountered most frequently in the summer $(n=39,32.5 \%)$ and least frequently in the winter $(n=13,10.8 \%)$. Emergency presentations due to exposure to physical violence were most frequent in July ( $\mathrm{n}=16$ $13.3 \%)$, followed by April ( $n=14,11.7 \%)$. The number of cases was 12 for Wednesdays and varied between $17^{\text {th }}-19^{\text {th }}$ on the other days of the week (Figure 1).

General body trauma (GBT) was determined in $43.3 \%$ of the patients. The most common injury site was the head $(n=39$, $32.5 \%)$, followed by the extremities $(n=21,17.55 \%)$. Of the patients, $77.5 \%$ were diagnosed with soft tissue trauma (STT), $10.83 \%$ with ecchymosis $(n=10)$ or hematoma $(n=3)$. One patient

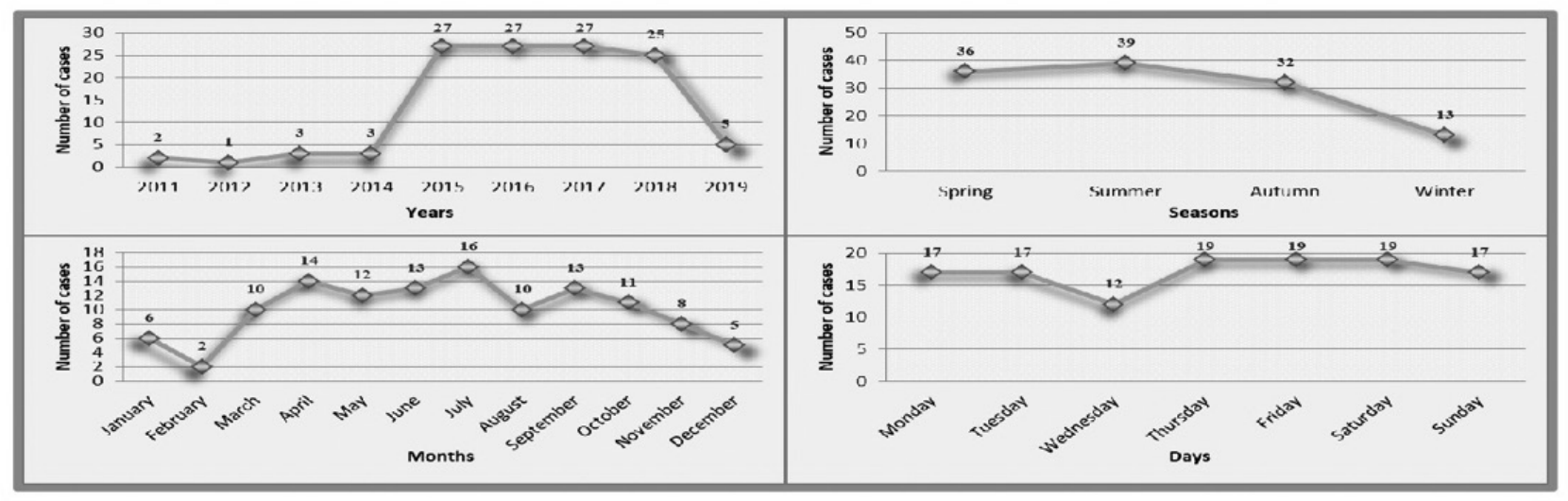

Figure 1. The number of emergency presentations due to exposure to physical violence by years, seasons, months and days 
was determined to have multiple trauma involving ecchymosis and incision. Consultations were requested for 24 (20\%) patients. The ear-nose-throat (ENT) clinic was consulted the most commonly ( $n=10,41.7 \%)$.

Table 1. Demographic characteristics and time of presentation

\begin{tabular}{|c|c|c|}
\hline & Median (IQR) / n & Min-max / \% \\
\hline Age & $15(4)$ & $4-18$ \\
\hline \multicolumn{3}{|l|}{ Sex } \\
\hline Female & 35 & 29.2 \\
\hline Male & 85 & 70.8 \\
\hline \multicolumn{3}{|l|}{ Time of presentation } \\
\hline 00:00 a.m. - 07:59 a.m. & 19 & 15.8 \\
\hline 08:00 a.m. - 03:59 p.m. & 32 & 26.7 \\
\hline 4:00 p.m. - 11:59 p.m. & 69 & 57.5 \\
\hline
\end{tabular}

According to ISS levels, minor injuries (ISS $\leq 3$ ) were determined in the patients at a rate of $87.5 \%$, and moderate injuries (ISS; 4-8) at $12.5 \%$, with no patients with an ISS $\geq 9$.

The evaluation of the patients' conditions based on sex revealed a significant difference between females and males in terms of the site of injury $(p=0.013)$. Follow-up analysis determined that injuries to the head area caused this difference. Injuries to the head area showed higher rates than expected in males than females ( $n=34,87.2 \%)$. Diagnosis, consultation status, and ISS characteristics were not significantly different across sexes (respectively; $p=0.126, p=0.132, p=0.226$ ).

Analyses did not determine significant differences in site of injury, diagnosis, consultation status, ISS characteristics based on patient age (respectively; $p=0.600, p=0.247, p=0.674, p=0.346$, Table 2).

Table 2. Review of the patients' conditions based on demographic characteristics

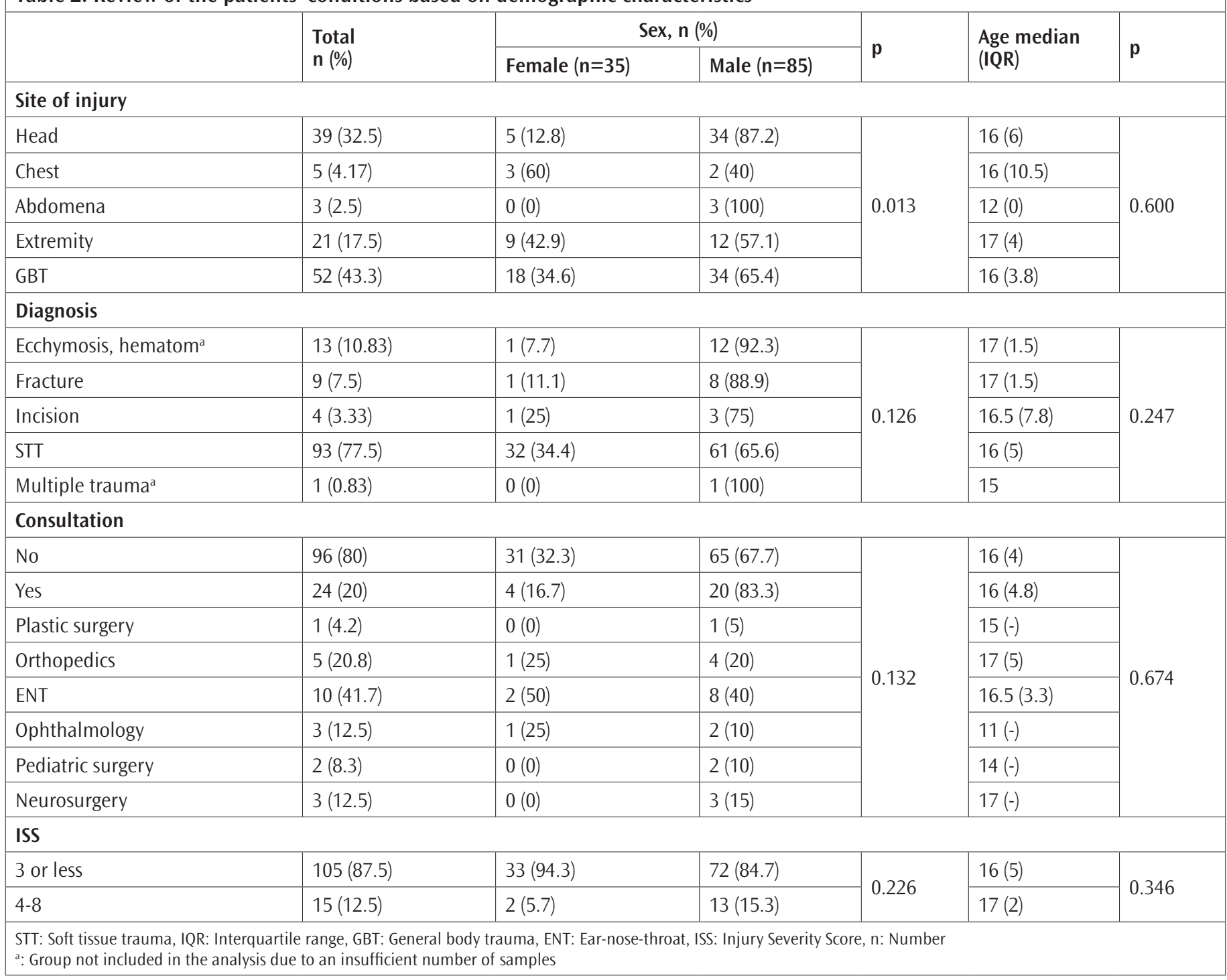


At least one injury site was significantly different in terms of ISS $(p<0.001)$. Using follow-up analysis, GBT was identified as the group that caused this significant difference. GBT was associated with significantly higher rates of minor injuries than expected when compared with other injury sites. Patients with GBT did not demonstrate any moderate injuries.

A significant difference was determined between the diagnosis groups in terms of ISS $(p<0.001)$. It was concluded based on follow-up analyses that this difference was primarily caused by the diagnosis of fracture, followed by the diagnosis of STT. Patients determined to have fractures showed more effective rates $(n=9,100 \%)$ of moderate injuries than expected compared with the other groups. Meanwhile, no moderate injuries were detected in patients with STT, as opposed to the expected prevalence.

Significantly more moderate injuries were found in patients for whom a consultation was requested $(n=14,93.3 \%)$ compared with others $(p<0.001$, Table 3$)$.
For patients who presented to the emergency service due to physical violence exposure, the lowest treatment cost was 15.5も, while the highest cost was 743.62も. The sites of injury associated with the highest median costs were the abdomen (369.79も) and chest (283.88も-357.1€), and the diagnoses associated with the highest median costs were incisions 251.34も (57.4) and STT (189.45も (304.5)も. In patients for whom consultations were requested, the departments associated with the highest median costs were ophthalmology (max: 575.37も) and ENT (max: 516.59も).

In the analyses performed concerning injury, diagnosis types, consultation status, and ISS evaluations, no significant differences were determined between the variable groups in terms of cost (respectively; $p=0.321, p=0.170, p=0.297, p=0.255$, Table 4).

\section{Discussion}

Emergency services have an essential role in identifying forensic events, which are among the most preventable health problems

\begin{tabular}{|c|c|c|c|c|}
\hline & \multirow{2}{*}{$\begin{array}{l}\text { Total } \\
\mathrm{n}(\%)\end{array}$} & \multicolumn{2}{|c|}{ ISS - n (\%) } & \multirow[b]{2}{*}{ p } \\
\hline & & $\begin{array}{l}3 \text { or less } \\
(n=105)\end{array}$ & \begin{tabular}{|l}
$4-8$ \\
$(n=15)$
\end{tabular} & \\
\hline \multicolumn{5}{|l|}{ Site of injury } \\
\hline Head & $39(32.5)$ & $27(69.2)$ & $12(30.8)$ & \multirow{5}{*}{$<0.001$} \\
\hline Chest & $5(4.17)$ & $5(100)$ & $0(0)$ & \\
\hline Abdomen $^{\mathrm{a}}$ & $3(2.5)$ & $3(100)$ & $0(0)$ & \\
\hline Extremity & $21(17.5)$ & $18(85.7)$ & $3(14.3)$ & \\
\hline GBT & $52(43.3)$ & $52(100)$ & $0(0)$ & \\
\hline \multicolumn{5}{|l|}{ Diagnosis } \\
\hline Ecchymosis, hematoma & $13(10.83)$ & $8(61.5)$ & $5(38.5)$ & \multirow{5}{*}{$<0.001$} \\
\hline Fracture & $9(7.5)$ & $0(0)$ & $9(100)$ & \\
\hline Incision & $4(3.33)$ & $3(75)$ & $1(25)$ & \\
\hline STT & $93(77.5)$ & $93(100)$ & $0(0)$ & \\
\hline Multiple trauma & $1(0.83)$ & $1(100)$ & $0(0)$ & \\
\hline \multicolumn{5}{|l|}{ Consultation } \\
\hline No & $96(80)$ & $95(99)$ & $1(1)$ & \multirow{8}{*}{$<0.001$} \\
\hline Yes & $24(20)$ & $10(9.5)$ & $14(93.3)$ & \\
\hline Plastic surgery & $1(4.2)$ & $1(10)$ & $0(0)$ & \\
\hline Orthopedics & $5(20.8)$ & $2(20)$ & $3(21.4)$ & \\
\hline ENT & $10(41.7)$ & $3(30)$ & $7(50)$ & \\
\hline Ophthalmology & $3(12.5)$ & $0(0)$ & $3(21.4)$ & \\
\hline Pediatric surgery & $2(8.3)$ & $2(20)$ & $0(0)$ & \\
\hline Neurosurgery & $3(12.5)$ & $2(20)$ & $1(7.1)$ & \\
\hline
\end{tabular}




\begin{tabular}{|c|c|c|c|c|}
\hline & \multirow{2}{*}{$\begin{array}{l}\text { Total } \\
\text { n (\%) }\end{array}$} & \multicolumn{2}{|c|}{ Costs ( $(€)$} & \multirow{2}{*}{ p } \\
\hline & & Median (IQR) & Min-max & \\
\hline \multicolumn{5}{|l|}{ Site of injury } \\
\hline Head & 39 (32.5) & $191.09(236.9)$ & $15.50-575.37$ & \multirow{5}{*}{0.321} \\
\hline Chest & $5(4.17)$ & $283.88(357.1)$ & $129.44-680.62$ & \\
\hline Abdomen $^{\mathrm{a}}$ & $3(2.5)$ & $369.79(-)$ & $106.61-475.85$ & \\
\hline Extremity & $21(17.5)$ & $111.00(322.7)$ & $15.50-487.51$ & \\
\hline GBT & $52(43.3)$ & $159.55(269.5)$ & $15.50-743.62$ & \\
\hline \multicolumn{5}{|l|}{ Diagnosis } \\
\hline Ecchymosis, hematoma & $13(10.83)$ & $133.55(287.2)$ & $15.50-575.37$ & \multirow{5}{*}{0.170} \\
\hline Fracture & $9(7.5)$ & $109.34(96.3)$ & $27.30-350.00$ & \\
\hline Incision & $4(3.33)$ & $251.34(57.4)$ & $245.36-320.96$ & \\
\hline STT & $93(77.5)$ & $189.45(304.5)$ & $15.50-743.62$ & \\
\hline Multiple trauma ${ }^{a}$ & $1(0.83)$ & $191.09(236.9)$ & $15.50-575.37$ & \\
\hline \multicolumn{5}{|l|}{ Consultation } \\
\hline No & $96(80)$ & $164.74(254.9)$ & $15.5-743.62$ & \multirow{8}{*}{0.297} \\
\hline Yes & $24(20)$ & $230.65(303.6)$ & $27.3-575.37$ & \\
\hline Plastic surgery & $1(4.2)$ & 149.80 & 149.80 & \\
\hline Orthopedics & $5(20.8)$ & $191.51(342)$ & $107.66-487.51$ & \\
\hline ENT & $10(41.7)$ & $116.43(319)$ & $27.3-516.59$ & \\
\hline Ophthalmology & $3(12.5)$ & $320.96(-)$ & $183.05-575.37$ & \\
\hline Pediatric surgery & $2(8.3)$ & $422.82(-)$ & $369.79-475.85$ & \\
\hline Neurosurgery & $3(12.5)$ & $350(-)$ & $101.15-406.45$ & \\
\hline \multicolumn{5}{|l|}{ ISS } \\
\hline$\leq 3$ & 105 (87.5) & $189.45(299)$ & $15.5-743.62$ & \multirow{2}{*}{0.255} \\
\hline $4-8$ & $15(12.5)$ & $116.2(220.6)$ & $27.3-575.37$ & \\
\hline
\end{tabular}

for children. No studies have been conducted exclusively on exposure to physical violence injuries in pediatric forensic cases, particularly in the pediatric age group. We think that our study will contribute to the demographic data of our country in this domain. Various consequent injuries were detected in patients in the pediatric age group who presented with the complaint of exposure to physical violence, the most common of which was STT. Injuries to the head area showed higher rates than expected in males than females $(n=34,87.2 \%)$. A significant difference was determined between diagnosis groups in terms of ISS $(p<0.001)$. Patients determined to have fractures showed significantly higher rates $(n=9,100 \%)$ of moderate injuries.

Meanwhile, no moderate injuries were detected in patients with STT, as opposed to the expected prevalence. GBT was evaluated as a minor injury at significantly higher rates than expected compared with other injury sites. No moderate injuries were encountered in patients with GBT.

Assault-related injuries are a significant cause of morbidity and mortality in the youth. Of these injuries, $30 \%$ are caused by exposure to physical violence by peers. According to the Centers for Disease Control and Prevention (CDC), exposure to physical violence is the second leading cause of death for those aged between 15-19 years and the fourth leading cause of death in those aged between 10-14 years (11). Meanwhile, in the 0-18 age group, the primary cause of non-fatal traumatic injury is nonintentional injuries (12). In the present study, the F/M ratio was $35 / 85$, and no deaths associated with physical violence were encountered. This can be due to the absence of political conflict and the low population in our region. 
In studies conducted in our country, intentional injuries constituted the second-largest trauma group after traffic accidents with a rate of $21.6 \%$. Among intentional injuries, exposure to physical violence was the most common cause (62.5\%). Exposure to physical violence was determined to comprise $13.5 \%$ of all forensic cases. Most of the patients exposed to such trauma were male (70.0\%). In another study conducted in our country, most of the forensic medicine reports of male patients involved the ages 15-18 years, while this age range was 7-14 for female cases; and the majority of forensic cases younger than 18 years were males (58.1\%). A recent national study reported more male pediatric forensic cases and that the most common age range was 7-10 years (13-15). In the present study, 120 child patients presented to the emergency service. The patients' median age was 15 (418) years, and $70.8 \%$ were male. The F/M ratio was $35: 85$. These values were consistent with other studies. The fact that individuals are highly influenced by their friends and environment during adolescence, and act without much thought, prioritizing their sense of independence, may lead to behaviors associated with exposure to physical violence. Particularly in boys, this situation was reported to increase the likelihood of exposure to physical violence (13).

In a study by Kalkan et al. (14), the cases' seasonal distribution revealed that the majority of the cases (45.5\%) presented in the summer, with $38.8 \%$ in August. In our study, $57.5 \%$ of the presentations were made between 4:00 p.m. - 11:59 a.m. Cases were encountered most frequently in the summer $(n=39,32.5 \%)$ and least frequently in the winter $(n=13,10.8 \%)$. Due to physical violence exposure, emergency presentations were most frequent in July $(n=1613.3 \%)$, followed by April $(n=14,11.7 \%)$. We reason that the schools being closed and children spending more time outside during the summer contribute to the increase in exposure to physical violence in the summer.

According to the CDC data, non-fatal injuries are more common in boys than in girls in the 1-19 age range (16). Males were exposed more to behaviors reinforcing masculinity and risky situations that might result in early death. On the other hand, females were the primary victims of domestic physical violence. Close partners comprised $40 \%$ of the main perpetrators of female exposure to physical violence (17). Our study could not obtain adequate data regarding the perpetrators of physical violence due to the lack of relevant data in the system.

Many studies have reported the head-neck and upper extremities to be the body parts that are injured the most commonly. Again, in single-site trauma, head-neck is the most common site of injury $(18,19)$. In the study by Kalkan et al. (14), almost half of the patients (49.3\%) had trauma in the head-neck area, and $23.6 \%$ in the lower extremities. The upper extremities were the third, and the abdomen was the fourth area. Further, the head-neck area (34.4\%) was affected the most commonly in single-site trauma. In the present study, $43.3 \%$ of the patients were determined to have GBT. The injuries were most common in the head area $(n=39,32.5 \%)$, followed by the extremities ( $n=21,17.5 \%)$. STT was present in $77.5 \%$ of the patients, and there was a significant difference between females and males in terms of the site of injury ( $p=0.013)$. Injuries to the head area showed unexpectedly higher rates in males than females $(n=34,87.2 \%)$.

Various scoring systems are being used to determine the severity of trauma and predict mortality in trauma cases. Some of these scoring systems were constructed based on physiological parameters; some were constructed based on anatomical localization, and others using both (20). GCS is a physiological scoring system. It is used widely worldwide in the evaluation of the state of consciousness and identification of coma (21). ISS is an anatomical scoring system. It is computed by dividing the body into six areas (head-neck, face, thorax, abdomen, extremities, other). The score varies between 1-75, and a score of 16 or higher indicates significant trauma (22). When Kalkan et al. (14) evaluated their cases concerning trauma severity, the injury was found to be non-life-threatening in most cases. Basic medical intervention was sufficient, and bone fractures did not occur. They did not have any cases resulting in death.

Most of the cases were evaluated as minor or moderate injury. This situation was interpreted as the most important factor explaining the low hospitalization rates and the $0.0 \%$ mortality rate (14). There was a significant difference between the diagnosis groups in terms of ISS $(p<0.001)$ in our study. Based on followup analysis, this difference was caused primarily by the fracture diagnosis, followed by the STT diagnosis. Patients determined to have fractures $(n=9, F=1, M=8)$ showed more significant rates $(100 \%)$ of moderate injuries than expected compared with others. Meanwhile, as opposed to the expected prevalence, no moderate injuries were detected in patients with STT.

Significantly more moderate injuries were determined in patients for whom a consultation was requested ( $n=14,93.3 \%$ ) compared with others $(\mathrm{p}<0.001)$. In our study, consultations were requested for 24 (M/F: 20/4) patients, most commonly from the ENT clinic $(n=10,41.7 \%)$ and the orthopedics clinic $(n=5$, $20.8 \%$ ), in descending order of frequency.

Childhood injuries exert significant pressure on families, societies, and health systems. The first step in reducing this injury burden is identifying the causative risk factors and devising strategies to eliminate these (23). Apart from the psychosocial effects of injuries, their burden on national expenditure is remarkably high. The annual economic burden of all Canadian 
citizens' injuries was estimated at 26.8 billion dollars (24). In the present study, for patients who presented to the emergency service due to physical violence, the lowest treatment cost was 15.5€, while the highest cost was 743.62も. The injury sites associated with the highest median costs were the abdomen (369.79も) and chest (283.88も-357.1 associated with the highest median costs were incisions 251.34 (57.4) and STT (189.45も (304.5)も.

\section{Study Limitations}

The study's retrospective design and the inclusion of the limited number of patients based on the data present in the hospital records.

\section{Conclusion}

Most of the physical violence cases were adolescents. It is essential to determine the characteristics associated with the injuries and trauma profiles. Such data can be used to bolster the interventions aimed at fostering a safe environment for children. Epidemiological data obtained in such studies should be considered when instituting preventive measures against injuries and constructing injury control programs.

\section{Acknowledgements}

I would like to thank everyone who contributed to this study.

\section{Ethics}

Ethics Committee Approval: An ethics approval was obtained from Düzce University Ethics Committee (approval number: 2020/223, date: 19/10/2020).

Informed Consent: Retrospective study.

Peer-review: Externally peer-reviewed.

Financial Disclosure: This study did not receive financial support.

\section{References}

1. Albert M, Mc Caig LF, Uddin S. Emergency department visits for drug poisoning: United States, 2008-2011. NCHS Data Brief. 2015;4:1-8.

2. Centers for Disease Control and Prevention National health statistic scenter: Emergency room visits. Available at: https://www.cdc.gov/nchs/fastats/ emergency-department.html

3. World Health Organization. (2014). Injuries and violence: the facts 2014. Available at: https://www.who.int/violence_injury_prevention/ media/news/2015/Injury_violence_facts_2014/en/\#: :text=Injuries\%20 account $\% 20$ for $\% 209 \% 25 \% 20$ of, fatal\%20injuries\%20which\%20require $\% 20$ treatment

4. Taplak AȘ, Tubaș F, Polat S. A retrospective records-based cohort of 1,082 pediatric forensic cases presenting to the emergency department. J Emerg Nurs. 2020;46:373-83.
5. Korkmaz MF, Bostancı M, Tutanç M. An Evaluation of the hospitalized pediatric forensic cases at a tertiary hospital. J Pediatr Emerg Intens Care Med. 2019;6:140-6

6. Kadıoğlu E. Pediatrik adli vakalar: Acil servis deneyimi. Türk J Adli Med. 2018;32:1-9.

7. Sumner SA, Mercy JA, Dahlberg LL, Hillis SD, Klevens J, Houry D. Violence in the United States: status, challenges, and opportunities. JAMA. 2015;314:47888.

8. Çoltu M, Durak D, Fedekar R. Evaluation of forensic cases applied to Emergency Department of Uludag University Hospital. Bull Legal Med. 2000;5:36-40.

9. De Leeuw M, Jacobs W. Forensic emergency medicine: old wine in new barrels. Eur J Emerg Med. 2010;17:186-91.

10. Yousefzadeh-Chabok S, Kazemnejad-Leili E, Kouchakinejad-Eramsadati L, Hosseinpour M, Ranjbar F, Malekpouri R, et al. Comparing Pediatric Trauma, Glasgow Coma Scale and Injury Severity scores for mortality prediction in traumatic children. Turk J Trauma Emerg Surg. 2016;22:328-32.

11. Centers for Disease Control and Prevention. Web-based Injury Statistics Query and Reporting System (WISQARS). Available at: http://www.cdc.gov/ injury/wisqars/index.html

12. Korkmaz T, Erkol Z, Kahramansoy N. Acil Servise Gelen Pediatrik Adli Olguların Değerlendirilmesi: Retrospektif Bir Çalıșma. Med Bull Haseki. 2014;52:271-7.

13. Yıldııım A. Acil servise başvuran çocukluk çağı adli olgularda travma profili ve istemli yaralanmaların özellikleri: retrospektif bir analiz. Klinik Tıp Pediatri Derg. 2016;8:34-9.

14. Kalkan EA, Yıldırım A, Akdur O. Trauma and ıntentional ınjury characteristics of pediatric forensic cases applying to emergency room acil servise başvuran çocuk adli olgularda travmaların ve istemli yaralanmaların özellikleri. J Clin Analytic Med. 2016;7:668-71

15. Demir ÖF, Aydın K, Turan F, Yurtseven A, Erbil B, Gülalp B. Acil servise başvuran çocuk adli olguların analizi. Turk Arch Ped. 2013;48:235-40.

16. Borse N, Sleet DA. CDC childhood injury report: patterns of unintentional injuries among 0-to 19-year olds in the United States, 2000-2006. Fam Community Health. 2009;32:189.

17. Stöckl H, Devries K, Rotstein A, Abrahams N, Campbell J, Watts C, et al. The global prevalence of intimate partner homicide: a systematic review. Lancet. 2013;382:859-65.

18. Sever M, Saz EU, Koșargelir M. Bir üçüncü basamak hastane acil servisine bașvuran adli nitelikli çocuk hastaların değerlendirilmesi. Ulus Travma Acil Cerrahi Derg. 2010;16:260-7.

19. Acar YA, Kılıç E, Bilgiç S, Ak M, Cömert B. Acil servise bașvuran 0-18 yaş grubu adli olguların özellikleri. Anatolian Journal of Clinical Investigation. 2010:4:148-51.

20. Güneytepe Üi, Aydın ȘA, Gökgöz Ş, Özgüç H, Ocakoğlu G, Aktaş H. Yaşlı travma olgularında mortaliteye etki eden faktörler ve skorlama sistemleri. Uludağ Üniv Tıp Fak Derg. 2008;34:15-9.

21. Teasdale G, Jennett B. Assessment of coma and impaired consciousness: a practical scale. Lancet. 1974;304:81-4.

22. Ateşçelik M, Gürger M. Acil servise künt travma ile başvuran hastaların incelenmesi. Firat Tıp Derg. 2013;18:103-8.

23. Frisch A, Croisier JL, Urhausen A, Seil R, Theisen D. Injuries, risk factors and prevention initiatives in youth sport. Br Med Bull. 2009;92:95-121.

24. Parachute C. The cost of injury in Canada. Parachute Toronto, ON; 2015. 